\title{
Infliximab treatment in co-existing behcet's disease and ankylosing spondylitis case presentation
}

\author{
Banu Ordahan1', Ali Yavuz Karahan 1*, Sevil Ceyhan Doğan², Levent Tekin', Seher Küçüksaraç ${ }^{1}$ and Ender Salbaş³ \\ *Correspondence: ayk222@hotmail.com

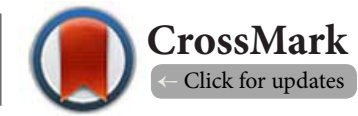 \\ 'Department of Physical Medicine and Rehabilitation, Beyhek State Hospital, Konya, Turkey. \\ ${ }^{2}$ Department of Physical Medicine and Rehabilitation, Cumhuriyet University School of Medicine, Sivas, Turkey. \\ ${ }^{3}$ Department of Physical Medicine and Rehabilitation, Ağri State Hospital, Ağri, Turkey.
}

\begin{abstract}
Only a few cases of coexisting Behcet's disease and Ankylosing Spondylitis have been reported in the literature. In this article, we aimed to present a male patient with co-existing Behcet's disease and ankylosing spondylitis. However, the effectiveness of infliximab therapy in treatment co-existing Behcet's Disease and Ankylosing Spondylitis which was reported in this paper makes it interesting.
\end{abstract}

Keywords: Ankylosing spondylitis, behcet's disease, coexistence, infliximab, therapy

\section{Introduction}

Behcet's disease (BD) is characterized by oral and genital aphthous and involvement of various organs such as eyes, skin, joints, central nervous system and blood vessels. Vasculitis is the main anatomic lesion [1,2]. Sacroilitis is rarely seen in $\mathrm{BD}[3]$. Ankylosing Spondylitis (AS) is the prototype of the seronegative spondyloarthropathy (SPA) group which involves the sacroiliac joint and the spine and results in spinal disability $[1,2]$. The claim whether BD is a sub-group of SPA is controversial [1].

In the recent years, co-existing $\mathrm{BD}$ and $\mathrm{AS}$ cases are more frequently identified $[4,5]$ in the literature and attention on the co-existence of these two inflammatory rheumatic diseases for which auto-immune mechanisms are held responsible in the etiology is becoming more pronounced. In this article, we present the clinical features of the case involving a 29 years-old male diagnosed with co-existing $\mathrm{BD}$ and $\mathrm{AS}$ and the results of Tumor Necrosis Factor-alpha (TNF-a) blocker (infliximab) treatment.

\section{Case presentation}

Twenty nine years-old male patient applied to the Physical Medicine and Rehabilitation Clinic with a complaint of back pain and morning stiffness lasting since 5 years and aggravating since 6 months. Diagnosed with AS about 13 months ago, the patient was describing back pain with inflammatory characteristics which aggravates with rest and relieves with exercise despite his ongoing sulfasalazine $2000 \mathrm{mg} /$ day and indomethacin 75 $\mathrm{mg} /$ day treatment. Sacroiliitis was detected on his magnetic resonance imaginings (Figure 1 ).

Back movements were painful in the physical examination.
Tenderness detected at enthesis points. Sacroiliac joints were sensitive to compression. Gaenslen's test was bilateral positive. Finger to ground distance was $16 \mathrm{~cm}$. Schober's test was $2.5 \mathrm{~cm}$ and modified Schober's test was $3.6 \mathrm{~cm}$. Neck, back and pelvis examination was normal. Recovering oral aphthosis and painful genital aphthosis was detected in the examination (Figure 2). The patient was diagnosed as Behçet's Disease according to the International Criteria for Behçet's Disease (ICBD) [5]. Neurological examination was normal. Erythrocyte sedimentation rate was $64 \mathrm{~mm} /$ hour, C-reactive protein (CRP) was $16 \mathrm{mg} / \mathrm{dl}(0-6)$, and rheumatoid factor was negative in laboratory examinations. Other routine blood examinations were normal. HLA-B27 and HLAB51 were positive. No rheumatologic medical history in patient's family.

Patient's Bath Ankylosing Spondylitis Disease Activity Index (BASDAI) value was scored as 6.6 and Bath Ankylosing Spondylitis Functional Index (BASFI) value as 6.4. Infliximab treatment was planned for the patient with uncontrolled disease activity with previous Nonsteroidal antiinflammatory drug (NSAID)'s and sulfasalazine use. Cardiologic and thoracic consultations of the patient were performed. Patient was taken isoniazid prophylaxis upon twice null Purified Protein Derivative (PPD) scores. Patient was administered a weekly $400 \mathrm{mg}(5 \mathrm{mg} / \mathrm{kg})$ intravenous infliximab infusion on Week 0 , Week 2, Week 6 and every 8 weeks subsequently. Sulfasalazine treatment was discontinued. Patient's BASDAI value was determined as 3.2 and BASFI value as 3.1 at the fifth cure of the treatment. Finger to ground distance was $13 \mathrm{~cm}$. Schober's test was 3.2 $\mathrm{cm}$ and modified Schober's test was $3.6 \mathrm{~cm}$. Neck, back and pelvis examination was normal. Recovering Also, laboratory 


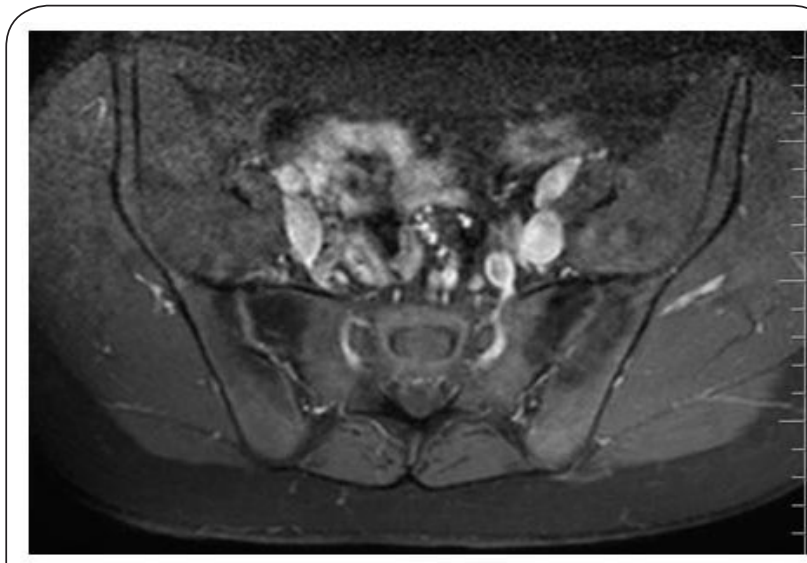

Figure 1. Magnetic resonance imaging of bilateral sacroiliac joint inflammation.

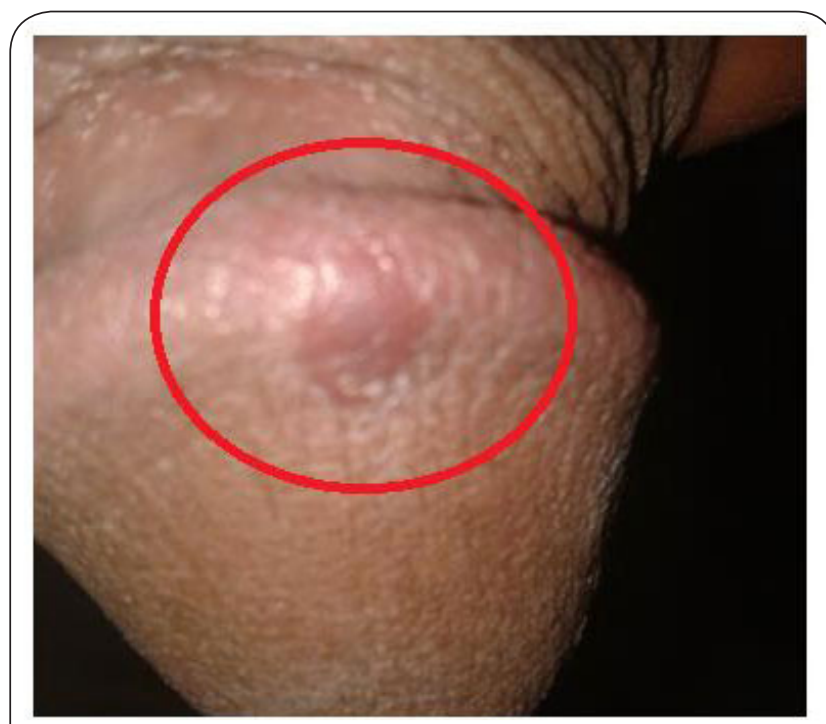

Figure 2. Aphthosis of glans penis was detected in the examination.

examinations were found to be normal.

\section{Discussion}

$\mathrm{BD}$ is an inflammatory disease characterized with oral and genital aphthous, uveitis, and skin lesions [4]. Arthritis is usually mono-or oligo-articular in $\mathrm{BD}$. Joint manifestations are $51 \%$, artheralgia $35 \%$, arthiritis $23 \%$ and AS $2 \%$ [5]. Knee, ankle, and wrist involvement is very frequent, while distal interphalangeal joint, vertebra and sacroiliac involvement is very rare [7]. AS is a chronic inflammatory disease in which vertebra and sacroiliac joint is involved $[6,8]$. Etiology of $B D$ and AS is not completely clarified. However, genetic predisposition, infection and environmental factors are the most emphasized subjects in both clinical pictures.

There are disputes on whether BD being a sub-group of SPA as sacroilitis is rarely seen in BD [2]. There are studies on co-existence of AS and sacroilitis in patients with BD. Taarit et al., found that $6 \%$ of 309 BD patients with joint involvement had sacroilitis and 2 patients had AS [3]. Oliveri et al., observed 6 sacroilitis cases out of 20 patients with Behcet's disease and 1 sacroilitis case out of 20 controls [6]. Dubost et al., [9] reported tree cases of BD and AS coexistence among 11 patients with BD. Borman et al., detected HLA-B27 positivity and HLA-B51 negativity in a 29 years-old female patient with co-existing AS and BD [7]. Similarly, Etaouil et al., found HLA-B27 positivity and HLA-B51 negativity in 2 cases with combined AS and BD [10]. Yazıcl et al., assessed 184 BD patients in Turkish population and found AS only in 1 case [11]. Yazıcı et al., indicated that the sacroiliac joint antero-posterior assessment differ greatly from person to person, therefore suggested the prevalence of sacroilitis in BD to be unclear [12]. Olivieri et al., recommended Computerized Tomography in order to reduce the differences arising from errors in the radiologic assessment of the sacroiliac joint. A relationship between HLA phenotypes of Behcet's disease and AS cases was detected in the literature [13]. There is HLA-B27 positivity in approximately $90 \%$ of SPA patients and HLA-B5 positivity in 60 to $80 \%$ of BD patients [8,11]. Incidence of HLA-B27 is more frequent in patients with co-existing $\mathrm{BD}$ and SPA $[8, \mathbf{1 3}]$. Kallel et al., found that $A S$ risk was higher in $B D$ patients with negative HLA-B5 [2].

Ocular involvement in patients with $\mathrm{BD}$ and patients with AS also differ. Anterior part of the eye is affected in HLA-B27related AS uveitis and it is benign. On the other hand, both anterior and posterior uveitis develop in $\mathrm{BD}$ and it may lead to vision loss in $25 \%$ of the patients $[2, \mathbf{8}]$.

Most commonly used anti-TNF agent in Behcet's disease is infliximab. Infliximab is used for the treatment of ocular involvement in particular, central nervous system (CNS) involvement, gastrointestinal system (GIS) involvement, muco-cutaneous findings, vascular involvement and arthritis. Intestinal BD is characterized by intestinal apthous and gastrointestinal symptoms. The medical treatment of intestinal BD includes corticosteroids and immunosupressants. There have been several reports of tumor necrosis factor-alfa blockers being successful in treatment of refractory intestinal BD. Chung et al., [14] reported on a patient who was diagnosed with intestinal Behcet's disease despite treatment with the fully humanized tumor necrosis factor alfa blocker (adalimumab) for underlying ankylosing spondylitis. This patient achieved clinical remission through the addition of a steroid and azathioprine to the adalimumab regimen. Early and positive responses were received in a study where infliximab treatment was evaluated retrospectively; etanercept treatment was started because of relative decrease in response, no infliximab treatment was considered necessary in one case and other 6 cases stayed in remission with their every 8 week infliximab treatment [3].

\section{Conclusion}

The coexistence of these two diseases is a rare entity but 
Ordahan et al. Journal of Rheumatology and Orthopedics 2014, http://www.hoajonline.com/journals/pdf/2055-7000-1-2.pdf

the number of case reports is increasing. The conditions will become more intelligible if many other studies are done. This paper reports the satisfied therapy of infliximab treatment in co-existing BD and AS.

\section{Competing interests}

The authors declare that they have no competing interests.

Authors' contributions

\begin{tabular}{|l|c|c|c|c|c|c|}
\hline Authors' contributions & BO & AYK & SCD & LT & SK & ES \\
\hline Research concept and design & $\checkmark$ & $\checkmark$ & $\checkmark$ & $\checkmark$ & $\checkmark$ & $\checkmark$ \\
\hline Collection and/or assembly of data & $\checkmark$ & $\checkmark$ & $\checkmark$ & $\checkmark$ & $\checkmark$ & $\checkmark$ \\
\hline Data analysis and interpretation & $\checkmark$ & $\checkmark$ & $\checkmark$ & $\checkmark$ & $\checkmark$ & $\checkmark$ \\
\hline Writing the article & $\checkmark$ & $\checkmark$ & $\checkmark$ & $\checkmark$ & $\checkmark$ & $\checkmark$ \\
\hline Critical revision of the article & $\checkmark$ & $\checkmark$ & $\checkmark$ & $\checkmark$ & $\checkmark$ & $\checkmark$ \\
\hline Final approval of article & $\checkmark$ & $\checkmark$ & $\checkmark$ & $\checkmark$ & $\checkmark$ & $\checkmark$ \\
\hline
\end{tabular}

Publication history

Editor: Fereydoun Davatchi, Tehran University of Medical Sciences, Iran.

Received: 18-Apr-2014 Final Revised: 17-May-2014

Accepted: 20-May-2014 Published: 29-May-2014

\section{References}

1. Chang HK, Cho EH, Kim JU and Herr H. A case of coexisting Behcet's disease and ankylosing spondylitis. Korean J Intern Med. 2000; 15:93-5. I PubMed

2. Kallel MH, Bejia I, Fournie B and Fournie A. Behcet syndrome with ankylosing spondylitis. Rev Rhum Engl Ed. 1995; 62:295-9. | PubMed

3. Taarit CB, Ben Turki $\mathrm{S}$ and Ben Maiz H. [Rheumatologic manifestations of Behcet's disease: report of 309 cases]. Rev Med Interne. 2001; 22:104955. | PubMed

4. Davatchi F, Shahram F, Chams-Davatchi C, Shams H, Nadji A, Akhlaghi M, Faezi T, Ghodsi Z, Larimi R, Ashofteh F and Abdollahi BS. Behcet's disease in Iran: analysis of 6500 cases. Int J Rheum Dis. 2010; 13:367-73. I Article I PubMed

5. The International Criteria for Behcet's Disease (ICBD): a collaborative study of 27 countries on the sensitivity and specificity of the new criteria. J Eur Acad Dermatol Venereol. 2014; 28:338-47. | Article | PubMed

6. Olivieri I, Salvarani $C$ and Cantini F. Is Behcet's disease part of the spondyloarthritis complex? J Rheumatol. 1997; 24:1870-2. | PubMed

7. Borman P, Bodur H, Ak G, Botan E and Barca N. The coexistence of Behcet's disease and ankylosing spondilitis. Rheumatol Int. 2000; 19:195-8. | Article | PubMed

8. Kucuksen S, Bagcaci S, Karahan AY, Sahin M and Ugurlu H. Coexistence of Behçet's Disease and Ankylosing Spondylitis. Eur J Gen Med. 2013; 10:112-4. | Pdf

9. Yildiz, N, Alkan H, Ardic F and Topuz O. Successful treatment with adalimumab in a patient with coexisting Behçet's disease and ankylosing spondylitis. Rheumatology international. 2010; 30:1511-14. | Article | PubMed

10. Etaouil N, Benyahya E, Bennis R and Mkinsi O. Ankylosing spondylitis and Behcet's disease in combination. Two case reports. Joint Bone Spine. 2002; 69:96-8. | Article | PubMed

11. Yazici $H$, Tuzlaci $M$ and Yurdakul $S$. A controlled survey of sacroiliitis in Behcet's disease. Ann Rheum Dis. 1981; 40:558-9. | Article | PubMed Abstract | PubMed Full Text

12. Yazici $H$, Turunc $M$, Ozdogan $H$, Yurdakul S, Akinci A and Barnes CG. Observer variation in grading sacroiliac radiographs might be a cause of 'sacroiliitis' reported in certain disease states. Ann Rheum Dis. 1987; 46:139-45. | Article | PubMed Abstract | PubMed Full Text

13. Olivieri I, Gemignani G, Camerini E, Semeria R and Pasero G. Computed tomography of the sacroiliac joints in four patients with Behcet's syndrome--confirmation of sacroiliitis. Br J Rheumatol. 1990; 29:264-7. I Article I PubMed

14. Chung SH, Park SJ, Hong SP, Cheon JH, Kim TI and Kim WH. Intestinal Behcet's disease appearing during treatment with adalimumab in a patient with ankylosing spondylitis. World J Gastroenterol. 2013; 19:5389-92. | Article | PubMed Abstract | PubMed Full Text

\section{Citation:}

Ordahan B, Karahan AY, Doğan SC, Tekin L, Küçüksaraç $S$ and Salbaş E. Infliximab treatment in co-existing behcet's disease and ankylosing spondylitis case presentation. J Rheumatol Orthop. 2014; 1:2. http://dx.doi.org/10.7243/2055-7000-1-2 